\title{
Islamic Education by Badiuzzaman Said Nursi in Secularic Period of Turkey
}

\author{
Nur Kholis \\ Yayasan Pendidikan Amanat Ummat Tengaran \\ cool.alcukil@gmail.com
}

DOI: $10.18326 /$ attarbiyah.v3i2.153-173

\begin{abstract}
This research discusses the role of Badiuzzaman Said Nursi in the islamic education happened in Turkey during the secularic period in the year of 1924 to 1950 . This is a library reseacrh with the historical method of analysis through the literature study and documentation of the works of Badiuzaman Said Nursi and another supporting literature. From the research obtained the information that Badiuzzaman Said Nursi plays the important role for giving the islamic education during the secularic period in Turkey. In addition, Badiuzzaman Said Nursi also creates a work under the title Risalah Nur to perform the islamic education during the secularic period. The Risalah Nur contains the education of tauhid, qur'anic interpretation and the fundamental rules of islam that successfully educate the people to secure the faith from the secularism.
\end{abstract}

Keywords: Badiuzzaman Said Nursi, Secularic Turkey, Islamic Education, Risalah Nur

\section{Introduction}

Secularic governance of Turkey begins in 1924 when the Uthmaniyyah Dynasti collapsed. The governance turns from islamic calliph system in to secularic republic system from 1924-1950 with the central figure namely Mustafa Kemal Attaturk (Amin. 2015: 28). By the collapse of the Uthmaniyyah Dynasty, it signs the end of the last islamic dynasty which has begun since 1294 . 
After the uthmaniyyah dynasty is collapsed, there arises the figure of Turkey namely Mustafa Kemal which also known as the Attaturk (the father of Turkey). He becomes the first president after the islamic calliph is changed by himself. He rules the government through the different customs from the previous leaders in all aspect. He aims to bring the Turkey in to an advanced country through his conception which is founded on the European (western) paradigms.

Mustafa kemal is only one of the nationalists Turkey which is influenced by the conception of the western paradigms. The nationalists see the advances of the country in the Europe are based on the freedom and the science. However Turkey before 1924, according to the nationalists is under the rigid governance which grasps the conservative rules of government that obstruct in achieving the advanced and modern Turkey. In the other hand, they wanted the Turkey to be the modern country through the reflection of the western values. So that they are endeavor in achieving their goals by the plan which has begun since 1913 and successfully achieved in 1923 through the appointment of Mustafa Kemal to be the president of Turkey.

After Mustafa Kemal is inaugurated to be the President of Turkey on October 29th 1923 by the Grand National Assembly which is established by himself, he starts to apply the nationalist conception in the government. By the believe that the modern Turkey could be achieved through the western system, he starts to divest the rules that potentially could obstruct his way. A big obstacle found by Mustafa Kemal to pursue 
his goal which is making Turkey to be an advanced country is the orthodoxy of the islamic religion. He believes that the islamic rules are not relevant with the spirit of nationalism which could bring Turkey in to the better condition as the western countries have achieved. The islamic rules according to the Mustafa Kemal and the nationalist will only restrain the spirit of making Turkey to be the advanced country (Vahide. 2007: 189). By this condition, Mustafa Kemal reforms the rules and the regulation through erasing all of the islamic influence both in the government and the social practice. The most tragical reformation he conducts, besides he abolishes the islamic calliph system on March 3rd 1924 and change it into republic, also on 1928 he cancels the chapter 2 of the institutional regulation in the year of 1924 about the appointment of Islam as the national religion of Turkey (Sani. 1998: 128). Turkey has no religion that is considered as the official religion since that time. The reformations have changed the face of Turkey to be a secularic country.

The modern Turkey then pionered by the believe that Turkey will only become an advanced country if Turkey abandones the values of Islam and follows the values of western (Vahide. 2007: 189). The government conducts three principals which are secularism, nasionalism and western paradigm as the national philosophy. As the result, the religion practices such as the tariqat, the call of adzan and the islamic teaching are forbidden since 1925. Furthermore, the education curriculoum is erasing all of the the islamic subjects from the schools and they are replaced by the science and the english subjects. Through the reformation in the education, the 
secularic Turkey is endeavor to avoid the islamic influence from the people especially the young generation.

The religiosity of the moslems of Turkey then gradually decreased by both of the teaching of islamic education which is stopped in the formal schools and the regulations which pressures the moslems from their freedom of performing their religious practices. This causes the risk for the moslems of Turkey to lose their faith of Islam.

In this situation arises an islamic figure who worries of the situation and concerns towards the islamic condition namely Badiuzzaman Said Nursi. On this cheos situation for the islamic religiousity, Badiuzzaman Said Nursi who is also an influential leader for the islamic community emits all of his efforts to entrench the secularism from the moslems of Turkey. He struggles to give moslems of Turkey the islamic thoughts to resist the policy which is made by Mustafa Kemal to ruin the islamics understanding. In this case, perform the islamic education is believed by Badiuzzaman Said Nursi as the important effort to secure the belief of the moslems of Turkey from the demolishing efforts for the islamic thoughts that is conducted by Mustafa Kemal to go towards secularism.

The efforts of Badiuzzaman Said Nursi in retaining the islamic religion in Turkey and how the islamic education is conducted by Badiuzzaman Said Nursi in the secularic period happening from 1924 1950 of Turkey will be the main focus of this research. Hopefully this 
research could give additional literature for the reading materials to know the effort of the islamic figures on the islamic education.

\section{Methodology}

This is a library research which means a research that the datas are searched and collected through the literatures in the library (Munawir. 2006: 133). The presentation of the data in this research is designed qualitative since the main focus of this research is about the history and the thought about a figure so that this research is cathegorized as qualitative (Prastowo. 2011: 21). Furthermore, the method used in this research is historical method which has a meaning according to Kuntowijoyo as a procedure of solving the problems using the data or inheritances from the past to understand the event in the past with the objective to reconstruct the past objectively and systematically to be a historical story to predict the present and future event (Kuntowijoyo. 1995: 89).

The steps of working in this research adopts the theory proposed by Poerwantana in the historical method which are: (1) Collect the objects and datas that come from a particular period and collect the relevant written materials, (2) Divide the authentic and un-authentic materials (3) Conclude the findings based on the authentic resources (interpreting), (4) Compose the findings and the trusted evidences to be a historical story. (Poerwantana. $1987: 25-26)$

Meanwhille, in collecting the datas, this research uses the technique of literature and documentation. The technique of literature 
according to Koentjaraningrat is a process of collecting the datas and various materials that are found in the library such as news paper, books, magazyne, script and the document which are relevant for the research (Koentjaraningrat, 1983 : 420). Moreover, the technique of documentation is the technique of collecting the data through the written artifact such as scripts, books about the theoretical views, theorems and the other books that concern to the problems of the research (Nawawi. $1991: 133)$.

Furthermore, the anaysis and presentation of this research is using the technique of qualitative by the basis of the historical datas about the islamic education conducted by Badiuzzaman Said Nursi in the secularic period that happened in Turkey.

\section{Discussion}

The Biography of Badiuzzaman Said Nursi

Badiuzzaman Said Nursi born in Nurs, a vilage in Bitlis territory of eastern Anatolia in 1879 . He is fourth of seven siblings of a religious family from the tribes of Kurdi. His father is an islamic teacher who is called as molla Mirza and his mother is Nuriye. His given name is Said, but due to his intelligent and his strength in memorizing many kinds of book, since he is a teenager he called by his teacher as Badiuzzaman which means the miracle of the era (Al-Salihi. 2010: 11).

Young Said Nursi learns from one islamic school to another islamic school and from one teacher to anoter teacher ince he is 3 years old. Often, he learns for a short period becouse he has mastered all of the 
subject that is given by the teacher. Once, he studies in Beyazid Islamic School under the teaching of Syeikh Muhammad Celali, he only spends three monts to study the basics of islamic religion. However, even he learns for three months, Said Nursi got the diplome degree from Syeikh Muhammad Celali and got the title of Molla (teacher) Said. During three monts, Said Nursi spends the days to learn and memorise the fundamental books. Due to his intelligence, the study that commonly requires 15 years to get the diplome degree only finished in three months (Amin. 2015: 32).

Said Nursi ends his journey for study in the islamic schools when he is teenager. He returns to his village and starts to give the people the islamic teaching. Due to his strong argument and the deep of intelliget in giving lecture, in a short period Said Nursi reaches his popularity as the best islamic schoolar in Bitlis. Furthermore, becouse of his famous, he receives many invitations to teach the people from many dignitarys in eastern Anatolia.

Said Nursi becomes a famous islamic shoolar since he is teenager. Due to his intelligent, Said Nursi is loved by the people and the dignitaries provides the accomodation for him to give islamic teaching. He is also asked to stay with the dignitaries in order to give them and the people the deeper understanding of Islam. However, Said Nursi does not only teach the people. He uses the free time to think about the conditions of Turkey and learn many kind of books as the dignitaries provide Said Nursi with the library and literature that he could access to sharpen his knowledge in various dissciplines. 
Once, he receives the request from the governoor of Bitlis to stay with him for two years and he sharpens his knowlede by studying fourty kinds of book in any major such as theology, qur'anic interpretation, syntax of arabic language, hadith and fiqh besides giving a preaching (Vahide. 2007: 28). Furthermore, Said Nursi being invited by the governoor of Van namely Hasan Pasha and Iskodrali Thohir Pasha which in this place, Said Nursi has a tought that Turkey should combine the science and the islamic subjects in the schools and he pioneers the establishing of the university of Medresetuz Zahra by the support of the governoor. In another occasion, Said Nursi being invited by a dignitary namely Tahir Pasha who provides him a big library that contains the books of science that in the last, he could memorise 90 books in 3 months from the diferent major (Amin. 2015: 33)..

Said Nursi grows to be a pious islamic schoolar. He does not only could give the people teaching through the preaching but also he gives the action. In 1912, when Turkey declares to join the world war 1, he involves himself in to the battle field. Through the influence of his vigorous, he is able to support the people by the preaching. However, he involves himself in the fights in order to give the people spirit of nationalism to defend the homeland and the religiousity. He leads the fight in the eastern Anatolia and fight from years to years to defend the eastern anatolia. However, by the world war one is won by Britain's Empire and its ally, Badiuzzaman and his troops are under arrest and exiled in the communist teritory of Russia. 
In 1918 Said Nursi and his troops return to Istanbul from the isolation. People wellcome Said Nursi joyfully. However, not long Said Nursi commemorating his gather, the dynamic in the government moves quickly. The secularists intrude in the government and weakens the role of the sultan.

Said Nursi is regarded as the treath for the government when the secularists are finally seize the power of the government and change Turkey to be secular in 1924. His preaching is bordered. In this time, Said Nursi is weakened in giving people the teaching and preaching of Islam through the prisons and allenieations. People are being separated from the islamic schoolars by the government. Many of the islamic schoolars are justiced by the death penalty without the clear accusation becouse they are considered as the treath for the government, including Said Nursi. However, thanks to his vibrant and influencing speeches, he could give the argumentation in front of the judicial that could save him from the death. Said Nursi is safe from the death penaly, but the government does not allow him to gather with the people. His life is then being arrested by the government in the prisons and the alleniation since 1926 in order to lessen his effort of igniting the islamic spirit for the moslems of Turkey.

Said Nursi lives in one prison and move to another prison during the secularic Turkey. There are at least three prisons to arrest Said Nursi such as Eskisehir, Denizli, dan Afyon. However, the prisons are not weakening the spirituals of Said Nursi. The prisons are regarded by Said 
Nursi as a Madrasah Yusufiah that could purify his religiousity (Faiz. 2017: 27).

Beside prison, Said Nursi also lives in the alleniation and move to another alleniation. They are Barla, Kastamonu, dan Emirdag. The purpose of the alleniation is the same, that is to weaken the power of Said Nursi in the religious effort. However, the alleniation becomes the place for Said Nursi to conduct his effort to battle his own people, the secularic Turks, through the Risalah Nur and he calls the alleniation as the Madrasah Nur (Vahide. 2007: 319).

Said Nursi dies in 1960 in the alleniation. However, his life has been dedicated for the islamic education for more than 30 years to protect the faith of Islam for the moslems of Turkey until it could be exist till nowadays and Turkey still have the spirit of Islam even though in the secularic period.

The Socio-Political Situation in Secularic Turkey

After the Uthmaniyyah Dynasti is decayed, on July 23rd 1923 the Lausanue Charter is signed that internationally Turkey is acknowledged as a Republic Country. In october 29th 1923, Mustafa Kemal inaugurated to be the first president of the Republic of Turkey. The government canged to be applying the western democratic system and the objective of the government also moves from islamic calliph in to the secularism and liberalism.

Mustafa Kemal gains a strong power by his party which is the People of Republic Party (Cumhuriyet Halk Partisi) that is a powerful party 
during the period. The People of Republic Party is established by Mustafa Kemal and becomes the basis for the nationalists and secularists figures.

By the power in presidential and the parliament, many reformation of the laws of the Turkey are made and being legalized. The laws are being reformed through the orientation of the advances of European countries (Talib. 2011: xix). For example, he legalized the regulations which are adopting and following the regulation in Switzerland and constructing some regulations by following the regulation model in Italy.

The government starts to make the reformation on march 3rd 1924 by reforming the educationn system. The government secularizes the education to perform the western education system. Then on may 30th 1924 he dissolves the ministry of wakaf becouse it uses the islamic principals and considered as contradicts to the secularist principals (Sani, Abdul. 1998. 127). He also moves the capital city from Istanbul to Ankara, close all of the vital mosque in Istanbul and replace the function Hagia Sophia from a mosque to be a museum (Talib. 2011: xx).

Many of the reformations conducted by the government of Mustafa Kemal are an endeavor to reduce and erase the role of islamic religion. One of the bigget regulation made by the government is happened in 1928 which the government cancels the chapter 2 of the institutional regulation in the year of 1924 about the appointment of Islam as the national religion in Turkey (Sani. 1998: 128). By the regulation, the government institutionally legalized Turkey to be a secularic country. 
However, the people of Turkey is consisted of Kurdic ethnic. They having conservative islamic understanding (Lapidus. 2000: 89). Moreover people of Turkey has been implanted by the values of islamic religion in the culture and social aspect since the period of Uthmaniyyah Dynasti for six decades. The effort of obligating the secularic ideology by the government to the people of Turkey is considered as a not relevant effort (Harun, Abdul. 1997: 50). The regulations made by the secularist government get opposed by the people through the strong refusals. Many of the moslem's schoolars lead the refusal movements in many city in Turkey to oppose the policies of the government. However, Mustafa Kemal and its governance is very rigorous government and has no forgiveness for the people who oppose the policy. The millitary is intructed to arrest the rebels and give them a capital punishment in front of the justicial process that is seen by many people. The occurence clearly intimidate the people and it successfully dampens the people to not to do the refusal activities so that the government could be unrestrained to regulate the society and continue to apply the regulations

Mustafa Kemal death on November 10th 1938. However, his death does not stop the goverment to sustain the secularism from the Turkey. The People of Republic Party is still dominating the parliament in the government. Therefore, the secularic government is carried by the successor of the Mustafa Kemal.

The government under the People of Republic Party that Mustafa Kemal is the main figure made many reformation in all aspects of the 
regulation to etablish Turkey as a secularic country. This ideologi is still carried out by the government through the People of Republic Party until 1950. However, in the 1950 the People of Republic Party looses the power in the election from the Democratic Party under the leader Adnan Menderez (Hatina. 2003: 51). Adnan Menderez elected as the prime minister of Turkey and he attempts to bring life the islamic religion in Turkey. This phase signs the end of the Secularictic Turkey.

Religious Situation in Secularic Turkey

After Mustafa Kemal elected as the president of Turkey, he becomes a dictator leader for 15 years of his reign. With the reformation during his governance, he tries to demolish the values and the cultures of the islamic religion and replaces it by the western culture (Susilo. 2016: 79).

Mustafa Kemal tries to separate the islamic religion from the governance in order to remove the influence of the islamic religion and the leaders of the tariqat by the reformation. On 1925, the government reforms the regulation on prohibition for the activity of Tariqat by closing the zawiyah (a place to assemble for islamic's sufi) and closes the grave of the saints. After that, in November 25th 1925 Mustafa Kemal announces the prohibition for the people of Turkey to wear the traditional apparels which are influenced by the islamic style, obliged men to wear with the Europen style and women to lose the veils which this policy is popular with the name of sapka kanunu or the Regulation of Cap (Vahide. 2007: 215). He also changes the resound of Azan with turkish and allows the reading Qur'an in turkish. 
On January 1st 1926, Musafa Kemal transpires the western gregorian calendar to replace the islamic calendar. Further, on February 17 th, he releases the new regulation in marriage which follows the regulation based on western tradition and deleted the use of islamic law on the mariage regulations.

The regulation made by Mustafa Kemal burries the islamic religion. Moreover, on 1928 when Mustafa Kemal erases the regulation of emphasizing islam as the national religion for Turkey, islam is truly being separated from the life of Turkey. The effort which is conducted by the secularic Turkey is an action to demolish the role and influence of the religion from the whole of Turkey.

The secularic government also reforms the education system by erasing the islamic subject from the curriculoum and young turkish are obligated to study the science from the understanding of Europe. This regulation endeavors to avoid people of Turkey from the islamic knowledge and also an effort to separate the islamic religion from the young generation of Turkey.

The religious situation in Turkey is decreased during the secularic period becouse of the effort of demolishing islamic influence by Mustafa Kemal and its government which is dominated by the figures of the People of Republic Party. The situation happened until 1950. After the People of Republic Party looses in the election in 1950, the government is under the control of Adnan Menderez. Adnan Menderez is a leader who concerns towards islam. By his governance, the islamic religiosity begins to increase. 
Islamic Education and Risalah Nur as an Education Path for Badiuzzaman Said Nursi

The effort of islamic education conducted by Badiuzzaman Said Nursi in the secularic period in Turkey is based on the reflection and the spirit of Qur'an which is interpreted contextually. A work of his contemplation based on the spirit of Qur'an born as the path for giving a teaching for the people under the title Risalah Nur.

Risalah Nur is a work of the result of his contemplation (tafakur) that he conducts in his allineation. As the Turkey is under the secularic government, Said Nursi is considered as a threat for the government so that from 1927-1950, he lives in the prisons and the allineations. Some of the allineation areas are Barla, Kastamonu, dan Emirdag that he calls the places as Madrasah Nur. While the prisons are Eskisehir, Denizli, dan Afyon which he calls as a Madrasah Yusufiyah. However, in these situation, Said Nursi could give the people teaching and education through writing the Risalah Nur when he could not struggle by the another effort (Faiz. 2013: 22).

The government under the president of Mustafa Kemal campaigns the secularic system as the philosophy to achieve the modern Turkey. He erases all of the islamic laws in the government and obliges the people to apply the system. One of the methods of his effort is conducting campaigns that islamic religion and islamic laws are not relevant in the effort to achieve a modern country in most of his spech. Then he also erases the islamic subjects from the education curriculoum. Therefore, the 
people's believe of the islamic religion gradually decreased. In this situation, Said Nursi is being called to cognizant the people about the important of tauhid (believe) for the life both in this world and herefter.

From the prisons and the allineations, Said Nursi nurtures the people by a handout that is written by his students through the hand writing which is called as the Risalah Nur. The handout contains the serial teaching of the islamic syariah, tauhid, the truth of the life in the hereafter and the main content of the Qur'an which is interpreted based on the situation in that time. The basic principals in the islamic teaching contained in the Risalah Nur revealed by Said Nursi which is explained by Ihsan Qasim Al-Salahi, an Islamic schoolar from Egypt that his work has been translated in to Bahasa Indonesia:

"Risalah Nur adalah kitab petunjuk kepada Alqur'an, sebagai penjelasan (tafsir) makna-maknanya, satu cahaya mukjizatnya, satu tetesan dari lautan Alqur'an, sinar dari mentarinya, satu hakikat dari harta karun ilmu hakikat, dan merupakan terjemahan maknawi yang bersumber dari mata air Alqur'an.” (Al-Salihi. 2010: 110).

Which means that Risalah Nur is an instructional book towards the Qur'an, as the explanation of its meaning, a light of its miracle, a droplet of the Qur'anic ocean, a shine of its sunbeam, an essence of its treasure of essential science and is a meaningful translation which has the source from a spring of the Qur'an. 
The basic principals belived in the educating process contained in the Risalah Nur are (1) use the logic and the sentiment or feeling to reveal the thruth of the Qur'an, (2) elaborate the nature of the creation of the universe and all of the creature in it and (3) aims to save the faith of the people. The activity conducted by Badiuzzaman together with his students is an effort to struggle for the existence of the faith for moslems and spread the understanding of the Qur'an peacefully and possitively (al-amal alijabi) in the pressures of secularic government. In facing the nation's degradation of moralic and spirituality, Said Nursi explains that it is necessary to conduct the moralic struggle through a verbal teaching by the words (al-jihad al-ma'nawi) in order to strengthen the belief and the people wish to apply the values of the religion in the social life (Vahide. 2007: 346).

The regulation conducted by Mustafa Kemal is pressuring the islamic religiousity. In the end of 1928, Mustafa Kemal restricts the use of Arabic in all of the literature in Turkey including the Qur'an. The press and publication which produce the literaturess in Arabic are sealed. In this situation, the Risalah Nur plays the important role in sustaining the Arabic teaching for the moslems of Turkey so that the use of Arabic in the Qur'anic manuscripts and the existence of Arabic are not demolished. In this difficult phase, the Risalah Nur is distributed secretly. However, the document of Risalah Nur could be spread broadly to the thousands of moslems' family in Turkey. The document of Risalah Nur is copied in many thousands by the hand writing. This condition unconciously teaches 
the people of Turkey about the Arabic which According to Richards and Rodgers considered as method of teaching the language through Total Phisical Response which means the emphasize on comprehension and the use of physical actions to teach a foreign language (Richards and Rodgers. 1999: 88). The effort conducted by Said Nursi through Risalah Nur is succed to sustain the Arabic language from the effort of demolishing through the education system by the government (Vahide. 2007: 216).

Risalah Nur plays the important effort in the struggle of education while Said Nursi is being arrested and allienated. It could give the taching of the nature of a faith to increase the awareness of the religion. The method of teaching explains the substance of the Qur'an to oppose the materialistic and naturalistic philosophy (al-falsafah al-tabi'iyyah) that exist in the effort of the secularic government. Also, it uses the tafakkur (meditation and observation) approach in formulating the problems that emphasizes in using darb al-amthal (the methapor) and muqaranah (comparation) to explain a thruth (Latif. 2008: 14).

Risalah Nur that is used as the school to educate the people by Said Nursi gives the big impact in the moslem's society. When the activity of Tariqat is forbidden by the secularic government in 1925, Risalah Nur replaces the important role of the Tariqat activity. It succesfully asks the people to continually do the zikr (religious prayer) and tafakkur (meditation) (Vahide. 2007: 266).

While the medresse (traditional islamic schools) and the mosques are closed by the secularic government, Risalah Nur is also giving a huge 
impact for the society in education. Risalah Nur gives the teching of the truth of iman (faith) and elaborate the substance of the Qur'an. The young generations of Turkey still able to study the islamic subjects while the medresse and the mosques as the center of islamic education are closed. The young generations of Turkey learns with their parents by making their homes as an institution for education through the Risalah Nur which is distributed by the students of Said Nursi to the society (Dunia Membaca Risalah Nur: 14).

Risalah Nur as the path of education has given Said Nursi a space to educate the people. It is an endevour to maintain the understanding of the islamic religion for the people to prevent the people for becoming atheism (al-ilhad). Through the Risalah Nur, Said Nursi could save the faith of moslems and educate the young generation of Turkey to have their faith of Islam.

\section{Conclussion}

The islamic education during the secularic period in Turkey is experiencing a degradation. This is caused by the education system that erasing the islamic subjects from the education curriculoum. The education curriculoum in the secularic government in Turkey is adopting the western system which the islamic subjects do not exist. By the degradation of the islamic education, the people's religiosity is also experiencing a degeneration. In this situation, Badiuzzaman Said Nursi appears to give the people an understanding of the importance of religiosity through his work Risalah Nur. Risalah Nur is the only effort 
that can be conducted by Said Nursi since he lives in the prisons and allienated during the secularic period. The Risalah Nur is distributed serially which contains the values of the Qur'an and the islamic subjects as the islamic education for the moslems of Turkey. With the thousands of follower from the islamic community, the Risalah Nur could be accepted by the people as the path of education for Said Nursi and the teaching in the Risalah Nur is made as the protector from the secularic ideology.

\section{Bibliography}

Al-Salihi, Ihsan Qasim. (2010). Said Nursi Pemikir dan Sufi Besar Abad 20 Membebaskan Agama a translation of Nazrah Ammah An Hayat Badiuzzaman Said Nursi. Jakarta: PT Raja Grafindo Persada.

Amin, Edi. (2015). Konsep Komunitas dalam Pemikiran dan Dakwah Said Nursi. Jurnal Komunikasi Islam, 5 (01), 27-50.

Faiz, Muhammad. (2013). Integrasi Nilai Spiritual, Intelektual dan Moral Dalam Konsep Pendidikan Said Nursi. Ar-risalah, 11 (01), 22-44.

Faiz, Muhammad. (2017). Risalah Nur dan Gerakan Tarekat di Turki: Peran Said Nursi pada Awal Pemerintahan Republik. Al-A'raf Jurnal Pemikiran Islam dan Filsafat. 14 (01), 23-46

Hatina, M. (2003). Historical Legacy and the Challenge of Modernity in The Midle East: The Case of Al-Azhar in Egypt. Muslim World, 93 (01), 51-68

Kuntowijoyo. (1995). Pengantar Ilmu Sejarah. Yogyakarta: Yayasan Bentang Budaya.

Munawir, Imam. (2006). Metode-Metode Penelitian Sosial. Surabaya: Usaha Nasional.

Nawawi, Hadari. (1991). Metodologi Penelitian Bidang Sosial. Yogyakarta : UGM Press. 
Poerwantana, Hugiono. (1987). Pengantar Ilmu Sejarah. Jakarta : PT. Bina Aksara.

Prastowo, Andi. (2011). Metode Penelitian Kualitatif dalam Perspektif Rancangan. Yogyakarta: ar-Ruzz Media.

Richards, Jack C and Rodgers Theodore S. (1999). Aproach and Method in Language Teching. Cambridge: Cambridge University Press.

Sani, Abdul. (1998). Lintasan Sejarah Pemikiran: Perkembangan Modern dalam Islam. Jakarta: Raja Grafido Persada.

Talib, Abdul Latip. (2011). Mustafa Kamal Ataturk Penegak Agenda Yahudi. Selangor: PTS Litera Utama Sdn. Bhd.

Vahide, Şükran. (2007). Islam in Modern Turkey, An Intellectual Biography of Bediuzzaman Said Nursi. New York: State University, AlBani. 